\title{
The plenipotentiary idea as Leitmotiv in John's Gospel
}

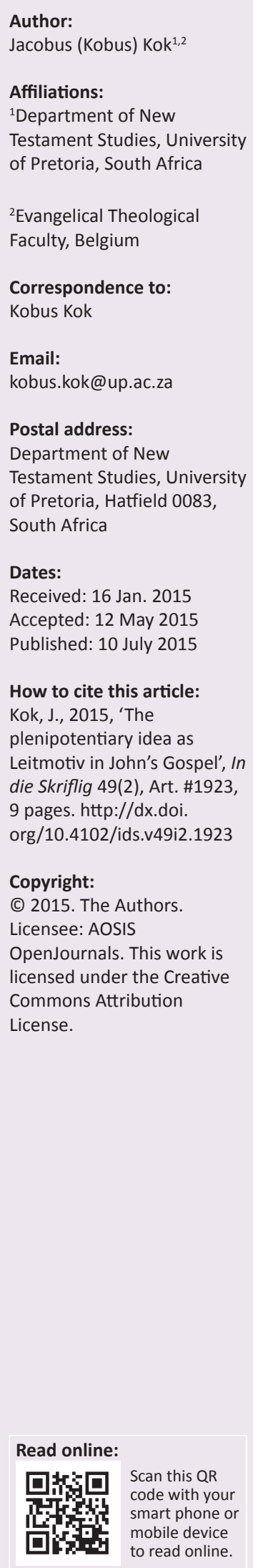

In this article the plenipotentiary idea in John's Gospel is studied in relation to Jewish institution(s) of agency. It is argued that the missionary idea in John's Gospel is a Leitmotiv (central or dominant theme) that integrates the Christology and Soteriology in the fourth Gospel. Jesus is presented as being God's empowered plenipotentiary who was sent by God to give life and to judge - qualities that were judged to be the prerogative of the Creator-God. After the resurrection, Jesus empowers his disciples to become plenipotentiaries who are called to continue the mission that God had started in and through Jesus. Unlike some scholars who argue that John is a sectarian writing aimed at an in-group, the author of this article argues that John's idea of mission is one that encourages an openness towards outsiders, motivated by love and other regarded, and expressed in a boundary transcending manner.

Opsomming: Gesantskap as leitmotief in die Johannesevangelie. In hierdie artikel word die konsep van gesantskap in Johannes se Evangelie in verhouding tot die Joodse konsepte van gesantskap bestudeer. Daar word aangevoer dat die missionale of gesantskapskonsep 'n leitmotief (sentrale of dominante tema) in Johannes se Evangelie is, en dat dit met die Christologie en die Soteriologie in die vierde Evangelie geïntegreer is. Jesus word as God se gevolmagtigde verteenwoordiger (gesant of plenipotensiaris) aangebied wat deur God gestuur is om lewe te gee en te oordeel - kwaliteite wat tradisioneel gesproke die prerogatief van God alleen is. Ná die opstanding bemagtig Jesus sy dissipels as sy gevolmagtigde verteenwoordigers wat geroep en gestuur is om die doel wat God in en deur Jesus begin het, te kontinueer. In teenstelling met sommige geleerdes wat beweer dat Johannes 'n sektariese geskrif is wat op die 'in-groep' in teenstelling met die 'uit-groep' gemik is, of dat Johannes geen sensitiwiteit vir buitestanders het nie, argumenteer die outeur van hierdie artikel dat Johannes se idee van sending 'n openheid teenoor buitestanders impliseer wat deur liefde gemotiveer is en op so 'n wyse uitgeleef behoort te word dat dit (sosiale en ander) grense transendeer.

\section{Introduction}

The word plenipotentiary relates to the Latin words plenus [full] and potens [power]. A plenipotentiary is thus an empowered person who acts on behalf of a certain person or group. In ancient Jewish thought in antiquity, a Sheliach was considered as an agent who represented the sender (cf. Anderson 2015: ad loc). In this article the way John's Jesus is presented as the plenipotentiary of God will be investigated, and how believers as God's agents are empowered to continue the mission of God as they are taken up in and become representative agents of the missio Dei. The purpose of this article is to illustrate why the plenipotentiary idea in John's Gospel could be considered as a Leitmotiv (central or dominant theme) in the fourth Gospel. In the process of arguing this point, a comparison between John and Jewish institution(s) of agency will be discussed and illustrated. ${ }^{1}$

\section{Excursus: Deuteronomy 18:15-22 as backdrop of Jesus as God's agent ${ }^{2}$}

Anderson (2015: ad loc) and others before him (cf. footnote 2 below) have argued convincingly, in my opinion, that John's agency motive should be interpreted against the background of Deuteronomy 18:15-22. The significant relationship between the Father and the Son in John's Gospel is developed around the agency-motive which makes use of the prophet-like Moses agency

\footnotetext{
1.Some of the perspectives in this article were developed in Kok's doctoral thesis. In this regard, cf. Kok (2008).

$2 . I$ would hereby like to thank one of the peer reviewers of this article who made helpful critical comments about the necessity of including a discussion of Deuteronomy 18:15-22 in the Johannine agency motif. The reviewer kindly pointed to the work of Borgen, Buehner, Meeks and Anderson. It was especially Anderson's essay on the Father-Son relationship in John in which I found particular helpful perspectives on the significant amount of parallels between the agency motif in John and the prophet-like Moses agency motif which is found in Deuteronomy.
} 
TABLE 1: Parallels between Deuteronomy 18:15-22 and the Gospel of John.

I (God) will raise up for them a prophet like you from among their brothers;

I will put my words in his mouth and he will tell them everything I command him.
John's Gospel

Jesus as prophet (Jn 1:17; 3:14; 6:32; 7:19, 22; 6:14-15).

Jesus speaks the words of God (Jn 5:18).

The teaching of Jesus is not that of his own $(3: 11,34 ; 5: 19 ; 10: 18$ and 7:16).

God commands Jesus to speak and act (Jn 12:49; 14:24).

God gives a new commandment through Jesus (13:34).

God sent Jesus (3:16; 20:30-31).

The mission of Jesus is God's will (5:30).

Jesus listens to and speaks his Father's words (Jn 5:30; 8:26).

People should listen to the words of the Son who was sent by the Father (Jn 3:36; 5:24; 10:3-4).

The Jews use this argument against Jesus (cf. Jn 5:18; 8:13, 53; 10:33).

Therefore Jesus must be killed (Jn 19:7; cf. Deut 18:20).

Irony: The Jews forsake God as their only King and proclaim Caesar is their king (19:15).

The prophesy of Jesus goes into fulfilment, showing that he was indeed sent by God (Jn 1:15; 26-27; 2:18-22; 10:41; 14:29).

Jesus' presence brings a massive division between those who are in and those who are out. The mere presence of Jesus confronts people with a choice to either recognise who Jesus is, namely the One who reveals God's truth (Jn 1:18; 9:33; 14:6), or to reject him and by implication not be obedient to the voice of God's prophet. Rejecting Jesus by implication means the rejection of God as sender.

Ironically people are more afraid of the Jews than of God (cf. Jn 9). motive found in Deuteronomy as typology for developing the missional agency of Jesus and that of believers. In his compelling argument, Anderson (2015) shows the significant parallels between Deuteronomy 18:15-22 and John which cannot be treated here extensively. Cursively some important elements will be pointed out which will be important to take into consideration when reading the rest of the article. Deuteronomy 18:18-22 states:

I (God) will raise up for them a prophet like you from among their brothers; I will put my words in his mouth and he will tell them everything I command him. If anyone does not listen to my words that the prophet speaks in my name, I myself will call him to account. But a prophet who presumes to speak in my name anything I have not commanded him to say, or a prophet who speaks in the name of other gods, must be put to death. You may say to yourselves, 'How can we know when a message has not been spoken by the Lord?' If what a prophet proclaims in the name of the Lord does not take place or come true, that is a message the Lord has not spoken. That prophet has spoken presumptuously. Do not be afraid of him. (NIV)

Those who know John's Gospel well, will immediately see the parallels which briefly are summarised in Table 1 ('Parallels between Deuteronomy 18:15-22 and the Gospel of John').

It is thus clear from the aforementioned that the Johannine Christology makes use of the Mosaic prophet typology in an effort to explain the relationship between the Father and the Son as well as the nature of the mission of Jesus as God's agent or plenipotentiary. However, we need to qualify the latter statement carefully. John's Jesus is clearly subordinate to the Father who has sent him to act on his behalf.

\footnotetext{
3.One of the external referees of this article remarked that it is important to add this specific point since: An important feature also to mention is the fact of the Son's subordination to the Father in John, in addition to being equal to the Father. This is a key basis for Arius' developing a subordinationist view of Christ, despite the fact a key basis for Arius' developing a subordinationist view of Christ, desp
that the view of Athanasius finally won the day in Christian theology.
}

The Father shows the Son what to do (5:20) and gives the Son works to do (assignments) (5:36). When John's Jesus is presented as being equal to $\operatorname{God}(5: 17,19,22 ; 10: 30$; $17: 21){ }^{4}$ or acting as God's plenipotentiary (5:22-23), one must understand that it is a position that was given to the Son by the Father and it forms part of the agency role and within the missional framework of the Missio Dei. Thus, subordination and equality is two sides of the same coin, but it is clear which side is the head, so to speak. God is the head, the primary sender and initiator of the mission of Jesus and at the end Jesus also has to 'report back' to God the sender (17). When Jesus leaves this earth (14), and the Paraclete is sent (14:26), it is essentially sent by (commissioned by) the (Son through the) Father to comfort the believers and remind and teach them of the words of Jesus which in essence was nothing other than the words of God himself 5:18ff.). A true plenipotentiary, in Jewish thought, will be a true representative of the one who sent him. John presents Jesus as exactly such a figure. We could thus concur with Anderson (2015:ad loc).

\section{God the Father-King and Jesus as plenipotentiary}

\section{The broken reality of this world: Two opposing representative families}

When a plenipotentiary is sent by an agent on a mission, it is typically associated with some agenda and connected to a particular envisioned outcome. According to John, Jesus is sent on a mission by God his Father, with a very particular purpose $(3: 16 ; 20: 30-31)$. The crisis that needs to be resolved in John's Gospel revolves around the idea that people are essentially alienated from God, who created

4. References from the Bible in this article indicated only by a chapter and verse(s) are from the Gospel of John. 
them (1:10). In John's symbolic world, people on earth are in a state of spiritual death (5:24). People are corrupt and enslaved by the devil $(8: 44)$ and by implication do not live the life of fullness (10:10) that God intended. The crisis is that people are not able to free themselves from this state of existence and spiritual crisis. The answer to the crisis can only come from 'above' (3:31). God is the God of life 1:1-4) who wants his creation to live in a reconciled and restored relationship with himself (3:16). The only problem is that his own people, those whom he created, have rejected him and neither recognise who he is 1:10), nor do they recognise the Son that he has sent to save them. This is the implicit irony,

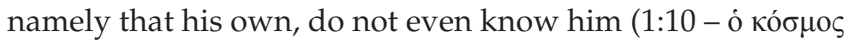

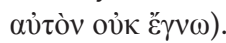

In John's narrative world, there are two qualitatively contrasting realities and two contrasting families: The family of God, the $\mathrm{King}^{5}(1: 12-\tau \varepsilon \dot{\varepsilon} \kappa \nu \alpha \theta \varepsilon \mathrm{\theta})$ on the one hand, and the family of the devil on the other $(8: 44-\dot{v} \mu \varepsilon i \bar{\varsigma}$

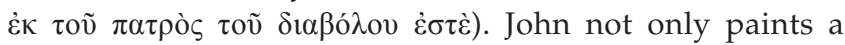
picture of two families, but also two possible ways of existing in this world. A person belongs to either one of these two families, and one is either able to (spiritually) see (3:3), or is (spiritually) blind (9:40-41). One either belongs to the world from below, or the world from above. The world from above $(1: 51 ; 3: 13,31)$ is qualitatively superior to the world from below $6: 51,58,63 ; 4: 13)$. The problem with those from below is that they are spiritually blind and do not see, hear, or do the will of God 9:40-41; 12:40-41). According to John 5:24, those who do not believe are in a state of spiritual death, that is they have not yet passed from death to life, and vice versa. They are the ones that function as agents of the evil one; and for that reason they do the

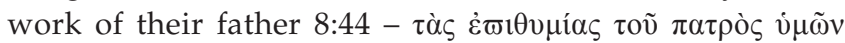

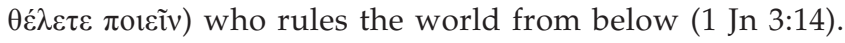
The irony is that they do not experience any blessing or life in fullness, but are themselves victims of their father's destruction (10:10) and are caught up in a state of spiritual death from which they cannot escape by their own means $(5: 24)$. Where there is spiritual death, there is destruction and alienation. ${ }^{6}$

\section{God sending his Son with the purpose of granting life}

God wanted to restore the broken relationship between humanity and himself. Consequently he took the initiative in resolving the crisis by sending his only Son $(3: 16 ; 20: 30-31)$. In John's symbolic world, God is the only one who is able to free people from their spiritual bondage. This particular crisis which God wanted to resolve out of his love for

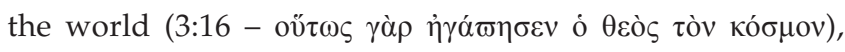
forms the implicit motivation for sending his only Son. The missionary motive and empowerment of the Son is therefore one of the most important dimensions of the

5.See Van der Watt (2000a) and his understanding of the family of the King in which he illustrates that the metaphor of a family is the conceptual metaphor John uses he develop his theology.
to delates that the meta

6.For a discussion of sin and alienation, cf. Kok (2008:147-157) and Van der Watt (2000a:296-303) who influenced Kok's train of thought.
Gospel of John (Waldstein 1990:311-312). It is around the missionary motive that the Christology and the Soteriology is developed. Van der Watt (2000a) convincingly argues that:

The mission is that of the Son by the Father. It is not just a mission of a family for the sake of the family, since Jesus came to gather those who belong to the Father $(6: 37 ; 17: 9-10)$. (p. 30)

In John 3:16 and 20:30-31 the purpose of the sending of the Son by the Father is clearly expressed, namely that the Son was sent to bring life. God is the source of life, and therefore Jesus, as his empowered Agent, acts on behalf of God when he speaks about life, or grants people new life as expressed through the healing narratives in John. In the Greek version of John 20:30-31, in the purpose statement of the fourth Gospel, this is expressed by the adverbial purpose conjunction, iv $\alpha$, which expresses the idea that the sending of the Son had a clear purpose (cf. 20:30-31), namely that people might thereby come to faith, or keep on believing (iv $\alpha \pi 1 \sigma \tau \varepsilon v ́[\varsigma] \eta \tau \varepsilon$ ), and as a result

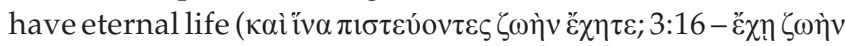
aínviov).

Borgen (1986:67), following C.H. Dodd, argues that: '[T] he status and function of the Son as God's delegated representative recalls the language of the OT prophets'. However, as Borgen correctly points out, Dodd underplays the missionary dimension, that is that the Son is commissioned and sent by the Father to be his representative. Bultmann on the other hand, according to Borgen (1986:67), 'rightly places the commissioning and sending of the Son in the very centre of the message of the Gospel'. Next we will reflect on the basic principles that inherently belong to the Jewish institution of agency, as mentioned by Borgen (1986:68-72) and its relation to John.

\section{Basic principles of agency in Jewish thought: A comparison between Siphre ${ }^{7}$ and John}

\section{The agent as the representative of the sender, sharing in the sender's nature}

Both Borgen (1986:68) and Witherington (1995:140) point out that John's missionary sending motive should be interpreted against the background of ancient missionary practices. Witherington (1995:140) correctly states that 'A person's agent, is himself' and Borgen (1986:68) agrees that 'the agent of the ruler is like the ruler himself'. In ancient times the agent was a plenipotentiary; he received full authority to act on behalf of the sender. It was important in antiquity that the agent be treated as if he was the sender himself. Any form of dishonour towards the agent would be treated as dishonour towards the sender. This way of

\footnotetext{
7.For access to Siphre and the latest translation thereof, see the followin link, viewed 26 Apr. 2015, from http://www blackwellreference.com/public/ tocnode?id=g9780631187288 chunk g978063118728824 ss1-529 Siphre on Numbers refers to the verse by verse exegetical Midrash on Numbers and it dates from the 2nd century (cf. especially Nm 5-12; 15; 18-19; 25:1-13; 26:52-31:24; and 35:9-34)
} 
TABLE 2: Comparison of John 12:44 with Siphre on Numbers 12:9.

John 12:44
In 12:44 - 'he who believes in Me, believes not in Me but in Him who sent Me'.
In 13:20 - 'he who receives any one whom I send receives Me'.
In 5:23 - 'he who does not honour the Son does not honour the Father who sent Him'.
In 12:45 - 'he who sees Me, sees Him who sent Me'.
In 14:9 - 'he who sees Me, has seen the Father'.
Jn 15:23 - 'he who hates Me, hates the Father'.

thinking is clearly seen in ancient sources. Borgen (1986) quotes Siphre on Numbers 12:9:

With what is the matter to be compared? With a king of flesh and blood who has a consul (agent) in the country. The inhabitants spoke before him. Then said the king to them, you have not spoken concerning my servant but concerning me. (p. 86)

From this perspective it is interesting to compare the latter with John 12:44 (see Table 2: 'Comparison of John 12:44 with Siphre on Numbers 12:9').

Borgen (1986:68) further points out that according to the halakhic principle, and especially as the idea of the agent as the sender's representative was developed by rabbis into some form of judicial mysticism, the agent was seen not only as having authority to act on behalf of the sender, but that the agent also shares in the qualities of the sender. This is most clearly seen in Qiddushin ${ }^{8} 43$ a that expresses the idea that 'the agent ranks as his master's own person' (Borgen 1986:68).

Against this background it is especially thought-provoking to look at the way John expresses his view of Jesus as God's agent. In John 10:30, John's Jesus states that 'I and the Father are one', and in John 10:38 he says that 'the Father is in Me, and I am in the Father'. Jesus says that those who see and believe the works that he does, will see, know and believe that he does the works of his Father (10:37) who has sent him into the world (10:36). This discourse clearly expresses the Jewish institution of agency well: God not only sends his Son to be his representative, his agent, but even more so, as an agent who shares in the very nature of the Sender.

\section{The agent is not greater than the sender}

A very important aspect in the Jewish institution of agency is the idea that the agent is never presented as being of equal status as the sender. In other words, the agent is always subordinate to the sender. Thus, the idea of (representative) unity between sender and agent inherently still implies a hierarchy in the relationship. We find this important idea both in John and in Jewish texts like Genesis

\footnotetext{
8.For more on Qiddushin 43a see the link viewed 20 Apr. 2015, from http:/l steinsaltz.org/learning.php?pg=Daf Yomi\&articleld= and also the link viewed 20 steinsaltz.org/learning.php?pg=Daf Yomi\&articleld= and also the link viewed 20
Apr. 2015, from http://www.sefaria.org/Rashi_on_Kiddushin.43a.1?lang=he\& Apr. 2015, from http://www.sefaria.org/Rashi_on_Kiddushin.43a.1?lang=he\&
layout=lines\&sidebarLang=all See also the link viewed 19 Apr. 2015, from layout=lines\&sidebarLang=all See also the link viewed 19 Apr. 2015, from http://ancientworldonline.blogspot.com/2012/01/online-soncino-babylonian-
talmud.html and specifically the link viewed 19 Apr. 2015, from http://www. halakhah.com/rst/nashim/30b\%20-\%20Kiddushin\%2041a-82b.pdf
}

Siphre on Numbers 12:9

Siphre - 'you have not spoken concerning my servant but concern ing me'.
TABLE 3: A comparison between John and Genesis Rabbah 78.

\begin{tabular}{ll}
\hline John & Jewish Texts \\
\hline Jn 13:16 - 'a servant is not greater than & Gen. $R .78$ - 'the sender is greater than \\
his master; nor is he who is sent greater & the sent'. \\
than him who sent him'. & \\
\hline
\end{tabular}

Rabbah $^{9}$ (henceforth Gen. R.) 78 as Borgen (1986:69) pointed out (see Table 3: 'A comparison between John and Genesis Rabbah 78').

The hierarchical relationship between the sender and the agent implies that the agent is in the service of the agent, and for that reason the agent should be focused on the commission and be obedient to the instructions of the agent. In early Jewish texts on the matter (according to Borgen 1986:96) this is evidently seen in texts like Erubin ${ }^{10}$ 31b-32a; Qiddushin 2:4 and Terumoth 4:4 and also in John's Gospel (see Table 4: 'Comparison between John and Jewish texts').

The commissioned agent in the Jewish legal institution was obliged to act on behalf of the sender and further the agents' agenda. This is subsequently noticeably seen in Baba Qamma ${ }^{11}$ 70a which is paralleled with John 12:31-32 (according to Borgen 1986:70). In John 12:49-50 Jesus says:

For I did not speak on my own, but the Father who sent me commanded me to say all that I have spoken. I know that this command leads to eternal life. So whatever I say is just what the Father has told me to say. (NIV)

Elsewhere (3:34), Jesus states that 'For the one (the Son) whom God has sent speaks the words of God ...'. For that reason Jesus' teaching is not his own. In John 7:16 Jesus clearly states that 'My teaching is not my own. It comes from the One (God) who sent me' (NIV). John's Jesus says in John 8:28 '... [I] do nothing on my own but speak just what the Father has taught me ...' (NIV). Borgen (1986:70) says that John follows the pattern that is also found in the Jewish halakah

9.Genesis Rabbah contains verse by verse running commentary (Midrash) on Genesis and dates approximately from the 3rd century ad. It can be accessed online in Hebrew from the link viewed 19 Apr. 2015, from http://www.daat. ac.il/daat/tanach/raba1/shaar-2.htm and also in translated form from the link viewed from 29 Apr. 2015, from http://archive.org/stream/RabbaGenesis/ midrashrabbahgen027557mbp\#page/n7/mode/2up

10.For access to the Erubin in translated form, cf. the link viewed 20 Apr. 2015 from http://www.halakhah.com/rst/moed/13a\%20-\%20Eruvin\%20-\%202a-26b. pdf

11.Baba/Bava Kamma/Qamma is a Talmudic tractate that deals with damages done and compensation thereof. It has 10 chapters (119 folios), the first six chapters dealing with damage caused without a deliberate form of criminality and a second part ( $b a b a$ ) (chapters 7-10) dealing with damage done by means of criminal acts (with intention). It explicitly deals with the matter of 'agency' and 'responsibility'. See http://jewishencyclopedia.com/articles/2277-baba-kamma for more information and access. 
In 5:41-43 - 'I do not accept glory from human beings ... I have come in my Father's name ...' (NIV).

In 6:38 - 'For I have come down from heaven not to do my will but to do the will of Him who sent Me' (NIV).

In 5:36 - 'For the works that the Father has given me to finish - the works that I am doing - testify that the Father has sent Me' (NIV).

Erubin $31 \mathrm{~b}-32 \mathrm{a}$ - 'It is a legal presumption that an agent will carry out his mission'.

Qiddushin 42b - 'I appointed you for my advantage, and not for my disadvantage'.

Terumoth 4:4 - 'If a householder said to his agent (Islohô), "Go and give a heave-offering", the agent should give heave-offering according to the householder's mind ...'

In 8:42b - 'I have not come on my own; God sent Me' (NIV).

$\dagger$, For access to the ancient Rabbinic sources, cf. the following link, viewed 21 Apr. 2015, from http://ancientworldonline.blogspot.com/2012/01/online-soncino-babylonian-talmud.html and specifically to see Terumoth, cf. the link, viewed $21 \mathrm{Apr}$. 2015, from http://www.halakhah.com/rst/zeraim/06\%20-\%20Trumos.pdf

(cf. Baba Qamma 72 a) whereby 'the sender transferred his own rights and the property concerned to his agent'. Interestingly enough we find this theme explicitly mentioned by Jesus in John 6:39 where he says: 'And this is the will of Him who sent Me, that I shall lose none of all those He has given Me ...' (NIV). One can see herein the idea of the sender transferring rights to the agent (cf. also 17:6). Jesus' mission is

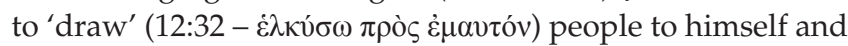
in so doing, by implication, draw people to God. This is part of his mandate (cf. 6:44).

\section{The purpose of Jesus' mission}

Jesus's mission was God's mission. The purpose of this mission is stated in several places in John's Gospel $(3: 16 ; 3: 39$; 20:30-31). In John 6:38-39 this is inter alia expressed very clearly:

For I have come down from heaven not to do my will but to do the will of him who sent me. And this is the will of him who sent me that I shall lose none of all those he has given me, but raise them up on the last day. (NIV)

The purpose of the sending of Jesus is that those who believe might receive eternal life (3:16) and not be judged.

Since people (according to John) do not have knowledge of the Father, one of the most important aspects of the mission of the Son revolved around the dimension of revealing the heart and will of God 1:10-11). One of the main purposes of God sending his Son, was to reveal his will to humanity and more importantly, to save them from eternal spiritual death $(3: 16 ; 6: 39)$. For that reason John's Jesus is presented as having been in a very close relationship with the Father, making him the empowered plenipotentiary of God. In the rest of the Gospel this important dimension is explained and unfolded.

\section{Those who see Jesus, see the Father}

In the prologue (1:18) the author of John places God and Jesus in very close (identity) proximity to each other. The opening verses (1:1-4) of the Gospel of John begin with the words:

In the beginning was the Word, and the Word was with God, and the Word was God. He was with God in the beginning.

12.See http://jewishencyclopedia.com/articles/2277-baba-kamma for more infor mation and access as well as the link viewed $29 \mathrm{Apr}$. 2015, from http://www. halakhah.com/rst/nezikin/31c\%20-\%20Baba\%20Kamma\%20-\%2062b-93a.pdf for Baba Kamma 74.
Through him all things were made; without him nothing was made that has been made. In him was life, and that life was the light of all mankind.

John 1:18 continues to express this intimate relationship by

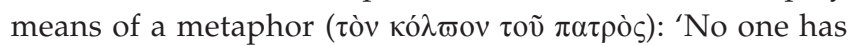
ever seen God, but the one and only Son, who is himself God and who is close to the bosom of the Father, and able to make him known'. In the Old Testament not even Moses had the privilege of seeing God. John's Jesus is presented not only as having seen God, but being with God and being

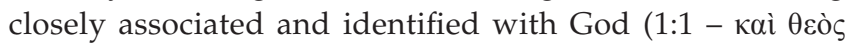
$\tilde{\eta} \nu$ ó $\lambda$ ó $\gamma_{0} \varsigma$ ). One can hardly think of a more differentiated or intimate way of describing the close relationship between God and Jesus. It is from God's presence, from his very being and from a position of being at his bosom

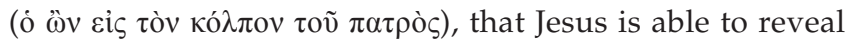

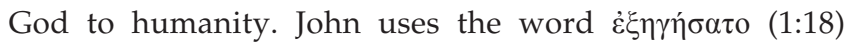
which according to Louw and Nida (1996) means 'to provide detailed information in a systematic manner "to inform, to relate, to tell fully"'. Jesus stands in such a close relationship with the Father that he can say that those who see him, see the Father $(12: 45 ; 14: 9)$. In John 3:36 the author of John's Gospel expresses the idea of Jesus as God's plenipotentiary clearly:

For the one whom God has sent speaks the words of God, for God gives the Spirit without limit. ${ }^{35}$ The Father loves the Son and has placed everything in his hands. ${ }^{36}$ Whoever believes in the Son has eternal life, but whoever rejects the Son will not see life, for God's wrath remains on him. (NIV)

Jesus is the one from above ( $\alpha v \omega \theta \varepsilon v)$ and it is only through him (14:6) that people can become part of the above (3:31 -

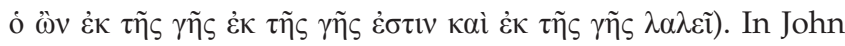
3:3 Jesus states that one must be born again spiritually to be able to 'enter' this new reality (cf. $\grave{\alpha} v \mu \eta \dot{~} \tau \Vdash \varsigma \gamma \varepsilon v v \eta \theta \tilde{n}$ ö $v \omega \theta \varepsilon v$,

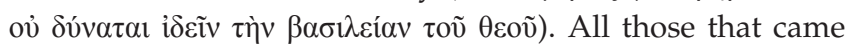
before were only able to either reveal that which is from below, or testify about the things that were to become true in and through Jesus (cf. 3:30).

In John 5:19-23, as Kok (2008:148) has indicated previously, the close proximity between the actions and words of the Son and that of the Father is accentuated. In John 5:19 John's Jesus says:

Truly, truly I say to you: the Son can do nothing by himself; he can do only what he sees his Father doing (cf. also Jn 7:18). 
The reason is that whatever the Father does, the Son also does

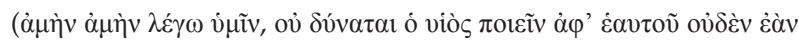

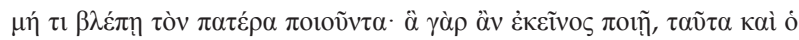

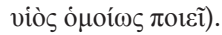

According to Hendriksen (1976:198), by means of the

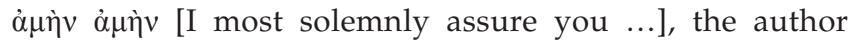
of John wants to stress a particular point which is very important in the particular pericope and the Gospel of John as a whole. John's Jesus is presented as saying that he is in effect unable to do anything which he had not seen his Father doing. For that reason scholars like Gnilka (1985:41) speak of the 'Einheit des Wirkens von Vater and Sohn' and Hendriksen (1976:198) of 'flawless correspondence'. Schnackenburg (1971:130) goes so far as to speak of 'Die Einheit des Zusammenwirkens ... nicht ein neben-order nacheineinder elfolgendes Wirken ... sondern ein gleichzeitiges, miteinander verbundenes' way of doing (cf. also Kok 2008:164). However, we need to note that it should not be thought that John wants to create the image of a 'Spiegelbield' (Haenchen 1980:275), but rather that those who see Jesus, actually see God in an analogical sense of the word (Keener 2003:648).

Köstenberger (2004:186) convincingly argues that the author of John wants to communicate the obedience and dependence of Jesus as the Son of the Father. In the western world today, individuality is seen as a virtue. When a son is different from his father, it is not by implication a negative thing. In ancient times this was not the case. In the 1st century $\mathrm{AD}$, a good son would try to be faithful to his father by doing things in such a way that it would please the father. A good son in ancient times would be a reflection of his father (Kok 2008:149, 164). Carson (1991:251) correctly observes: 'The Father initiates, sends, commands, commissions, grants; the Son responds, obeys, performs his Father's will and receives authority. In this sense, the Son is the Father's agent ...' This means that there is not a pure reciprocal relationship between the Father and the Son, but rather one of subordination, that is of the Son's dependence on the initiative of the (sending) Father (cf. Bühner 1977; Carson 1991:251; Harvey 1987:238-250). ${ }^{13}$ As a dependent and obedient Son, motivated by love, Jesus does what the

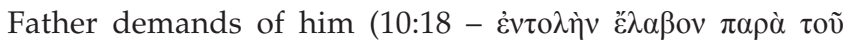
$\pi \alpha \tau \rho$ ó $\left.\mu_{0 v}\right)$, to such an extent that he would lay down his own physical life for the sake of achieving the purpose and missional plan of God.

\section{The sending Father showing the Son what to do}

In John 5:20 John's Jesus states that the Father loves the Son (cf. 3:35), and for that reason, the Father who had sent Jesus,

13.Carson (1991) correctly points out that: The Greek text of verses 19-23 is structured around four gar ('for' or 'because') statements. The first introduces the last clause of v. 19. The thought runs like this: It is impossible for the Son to take independent, self-determined action that would set him over against the Father as another God, for all the Son does is both coincident with and coextensive with all that the Father does. 'Perfect Sonship involves perfect identity of will and action with the Father' (Westcott 1. 189). It follows that separate, self-determined action would be a denial of his sonship (p. 251). shows him everything that he does. ${ }^{14}$ The purpose of this is that the Son could do the works of the Father that sent the Son. ${ }^{15}$ Because the Father and the Son stand in an intimate relationship with each other, the acts of the Son reflect the will of the Father. John's Jesus states that the communication between him and his Father is an on-going process and that the Father will show him 'even greater works' with the result that the Jews will be astonished (5:20). The greater

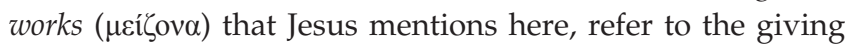
of life (5:21) and judgement. Jesus says that 'Just as the Father gives life, in the same way the Son gives life'. This is a very important aspect in John's Gospel that illustrates the plenipotentiary idea. Gnilka (1985:42; cf. also Kok 2008:165) correctly remarks that 'Die Toten lebendig zu machen, ist nach biblischer Auffassung die Prärrogative Gottes.' Jesus has been empowered by God with authority to act on behalf of God, so

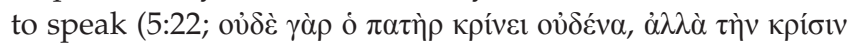

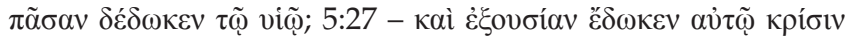

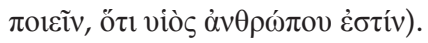

\section{Honouring the Son means honouring the Father and vice versa}

The purpose of this empowerment is that people should consequently (iv $\alpha$ ) honour the Son in the same way that they

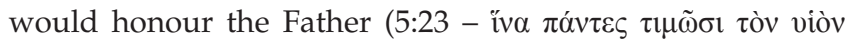
$\kappa \alpha \theta \dot{\omega} \varsigma \tau \iota \mu \tilde{\omega} \sigma \mathrm{\iota}$ tòv $\pi \alpha \tau \varepsilon \dot{\varepsilon} \rho \alpha)$. The clause(s) in John 5:21-22, begins with the Greek word, $\gamma \grave{\alpha} \rho$, which is the marker of cause or reason, and is followed by iv in John 5:23, which is the purpose conjunction which follows from the former. Jesus says that he has been empowered by God to give life and to judge $(5: 22)$, two sides of the same coin which according to the Old Testament is the exclusive prerogative of God (Gen 18:25; Rev 20:11-15); with the result (5:23) that (iv $\alpha$ ) those who honour him, by implication honour the Father (5:23).

John's Jesus is clearly presented as the plenipotentiary of God (Witherington 1995:14). It is understandable that the Jews in the 1st century would not easily accept this particular claim of Jesus. In a strong monotheistic religious context it is simply unthinkable to put any person, even a prophet, on the same level of honour as God. This is nothing short of blasphemy (Köstenberger 2004:188). Carson (1991) is of the opinion that here John goes beyond the plenipotentiary idea:

This goes far beyond making Jesus a mere ambassador who acts in the name of the monarch who sent him, an envoy plenipotentiary whose derived authority is the equivalent of his master's. That analogue breaks down precisely here, for the honour given to an envoy is never that given to the head of state. The Jews were right in detecting that Jesus was 'making himself equal with God' (vv. 17-18). (Carson 1991:254-255)

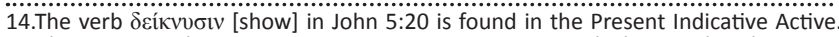
The Present indicates an action in process or a state in which no end to the action is expressed. For that reason it could be argued that it is an on-going action in is expressed. For that reason it could be argued that it is an on-going action in process at the time in which the statement was made. This point is illustrated in the same verse $(5: 20)$ where John uses the verb $\delta \varepsilon i \xi \varepsilon l$ [will show] which is in the relates to giving life $(4: 21)$ and being involved in the final judgement $(4: 22)$.

15.See Van der Watt (2000a) for a similar argument that influenced my thinking in this regard. 
When Jesus states that those who do not honour the Son, by direct implication do not honour the Father who sent him (5:23), he implies that those who do not accept Jesus, do not accept God. This means that only in and through Jesus will people stand in a correct relationship with God. Accepting Jesus thus becomes a prerequisite to salvation. In John 14:6, Jesus states that he is the way, the truth and the life and that no one will be able to come to the Father accept in and through

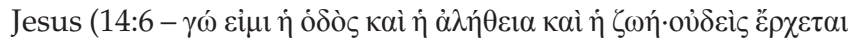

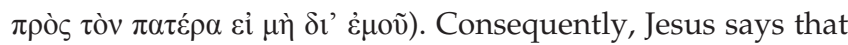
those who hear his word(s) and believe in him that sent Jesus, receive a new spiritual or existential identity: They are transferred from a state of existence in spiritual death, to a

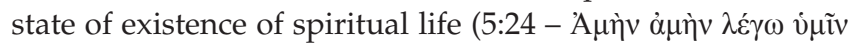

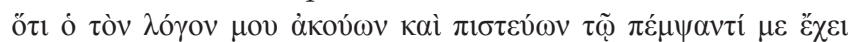

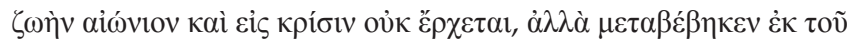

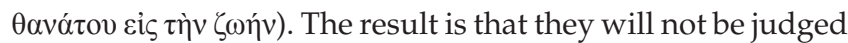

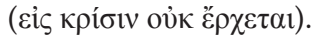

Those who do not believe, or do not accept Jesus, are in a state of spiritual death. They are alienated from God and will be judged $(3: 36 ; 12: 47-48)$. On the other hand, those who believe, will receive life in abundance (10:10) and they are also protected by God the Father (cf. 10:29; Kok 2008:168; Van der Watt 2000b).

\section{The agent reporting back to the sender}

Borgen (1986:71) also points to another aspect of the Johannine mission motive and the relation to the Jewish (or halakhic) institution(s) of agency. At a certain point in time an agent has to report back to the sender. In the halakah this is explicitly seen in P. [Palestinian Talmud] Hagigah 76d: 'Behold we send to you a great man as our shaliach, and he is equivalent to us until such time as he returns to us. ${ }^{16}$ The idea is found in John's Gospel. After Jesus completed his mission (4:34; 5:36; $17: 4 ; 19: 30)$, he reported back to God the sender. This is most clearly seen in John 13 and 17. In John 13:3 the narrator of John's Gospel mentions: 'Jesus knew that God had put all things under his power, and that he had come from God and was returning to God ...' (NIV). Then, in John 17:1-4, shortly before his arrest and crucifixion, Jesus is praying to God, the Sender, saying:

Father, the hour has come. Glorify your Son, that your Son may glorify you. For you have granted him authority over all people that he might give eternal life to all those you have given him. Now this is eternal life: that they know you, the only true God, and Jesus Christ, whom you have sent. I have brought you glory on earth by finishing the work you gave me to do.

Thus, it is clear that the author of John's Gospel draws on the metaphor of agency to express the fact that Jesus was sent with a divine purpose, to act on behalf of God, and to report back after his mission has been completed. But this is not where it ends. In the context where John's Jesus as agent,

16.See also Borgen (1968:143) in Neusner's (ed.) Religions in antiquity, as well as Bunim (2002:814) in Ethics from Sinai for the same argument supporting the point being made. reports back to the Father as Sender at the time towards the completion of his mission, Jesus as agent becomes the sender, empowering those who followed him.

In John 17:13-16 Jesus says to the Father:

I am coming to you now, but I say these things while I am still in the world, so that they may have the full measure of my joy within them. I have given them your word and the world has hated them, for they are not of the world any more than I am of the world. My prayer is not that you take them out of the world but that you protect them from the evil one. They are not of the world, even as I am not of it. (NIV)

Next (17:18), Jesus prays to God: 'As you have sent me into the world, I have sent them into the world'. This missional empowerment by Jesus occurs on the basis of the unity between the Father as Sender and the Son as Agent. In John 17:20-21 Jesus continues to pray and asks the Father:

My prayer is not for them alone, I pray also for those who will believe in me through their message, that all of them may be one, Father, just as you are in me and I am in you. May they also be in us so that the world may believe that you have sent me. (NIV)

The truth of what was spoken by Jesus in the Gospel needs next to be illustrated. The narrator built up tension in the narrative by means of the plenipotentiary idea. The question is what will happen when Jesus loses his own physical life. In the next chapter (18) Jesus is arrested and consequently he is crucified.

It is necessary to have a closer look at the way John envisions the empowerment of believers who are to become plenipotentiaries of God's missional plan. However, before this can happen, Jesus needs to lose his physical life and take it up again. It is only through the tunnel of death that the bright light of life could become visible. In John 12:24 Jesus states that there can be no life unless a seed falls into the ground and dies. For that reason Jesus has to die, before he will be able to return to the Father, and before it will be possible to send the disciples as plenipotentiaries.

\section{Jesus lays down his life in order to take it up again}

In John's Gospel the Father sends the Son as his representative agent with the purpose of giving spiritual life to people, as mentioned above. Jesus' ability to give life is illustrated as

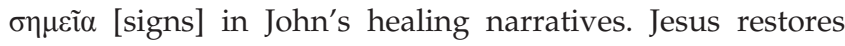
life that was lost. This is most clearly seen in John 11 where Lazarus dies. After having been dead for more than three

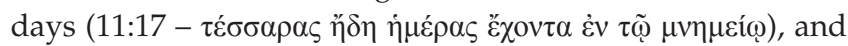

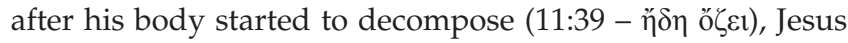
restored and resurrected Lazarus. In John 11:25 Jesus makes the statement that he himself is the resurrection and the life

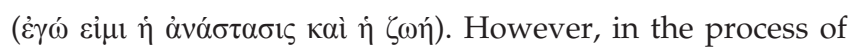
resurrecting Lazarus, Jesus prayed to God his father who was involved in the resurrection of Lazarus (11:41-42). The resurrection of Lazarus is thus a mediated-action. God resurrects Lazarus through Jesus as Agent. The question the 
implicit reader is left with is whether Jesus will be able to resurrect himself when he loses his own physical life (cf. Kok 2008:356).

In John's narrative world, against the background of increasing conflict with the Jews, Jesus eventually loses his own physical life on the cross. However, John, unlike some of the other Gospels, makes the point that Jesus laid down

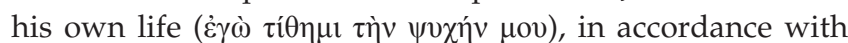
the mission and plan of God (10:17-19), in order to pick it

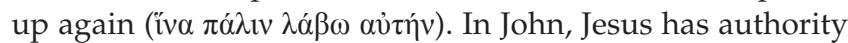
and power to lay it down, and to take it up again (10:18 -

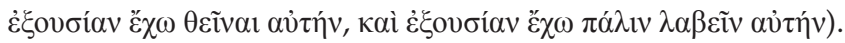
No one takes his life from him, but he lays it down himself

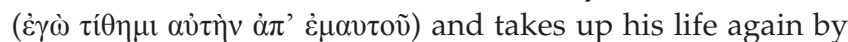

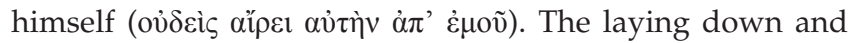

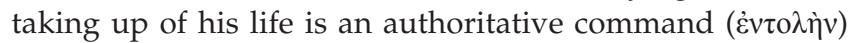
that Jesus received from God, the Sender (10:18; cf. Kok 2008:356; Van der Watt 2000b). What is important here is that Jesus says that he himself, by the authority of the Father, will take up his life once he has laid it down. This means that Jesus has been given the ability to give life, which is illustrated especially when he loses his own physical life and takes it up again in the resurrection. In John, Jesus rises from the dead, and in the process it is demonstrated that he is indeed the source of life, a point that John already made in the prologue (1:4).

\section{God who sent the Son also sends the disciples}

After the crucifixion, John paints a picture of the disciples who were hiding away behind closed doors in fear of the

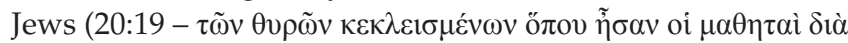

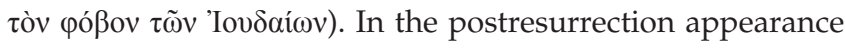
scene where Jesus appears to the disciples, a series of important actions occur that illustrate the plenipotentiary idea whereby Jesus empowers the disciples to become authoritative representatives of himself and of the mission of God. Following the resurrection, earlier utterances of Jesus, like those in John 17 discussed above, come to fruition.

In the first action, Jesus greets them with a word of peace:

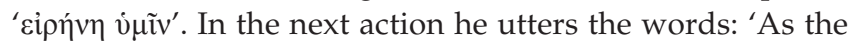

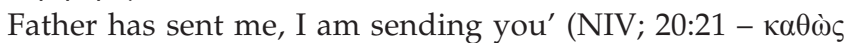

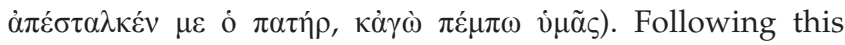

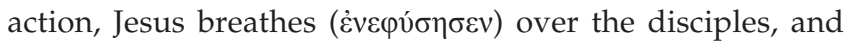
commands $^{17}$ them to receive the Holy Spirit $(\lambda \alpha \dot{\beta} \varepsilon \tau \varepsilon \pi v \varepsilon v \tilde{\mu} \alpha$ or $\gamma 10 \mathrm{v})$. This is the moment in John where the disciples become empowered agents of the same mission that God had started when he decided to send the Son to this world. Consequently, the disciples are sent into the world (17:18 -

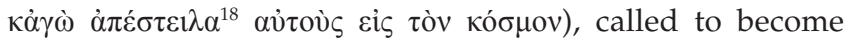

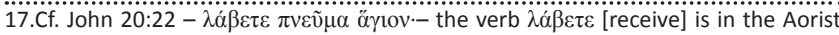
Imperative Active.

18.It is important to also take note of John 20:21 where John uses two different words for sending, namely $\alpha \pi 0 \sigma \tau \dot{\varepsilon} \lambda \lambda \omega$ and $\pi \dot{\mu} \mu \pi \omega$. Henrich Rengstorf (1964:398), points

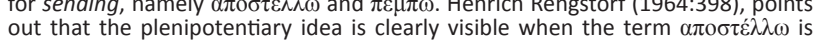
out that the plenipotentiary idea is clearly visible when the term $\alpha \pi 0 \sigma \tau \varepsilon \lambda \lambda \omega$ is
used in ancient literature. In John's Gospel the word $\pi \varepsilon \dot{\varepsilon} \mu \pi \omega$ is often used to say that used in ancient literature. In John's Gospel the wo plenipotentiaries - empowered agents of God's missional plan. For that reason Jesus also makes a statement that expresses the authority of the disciples as agents: 'If you forgive anyone's sins, their sins are forgiven; if you do not forgive them, they are not forgiven' (NIV; 20:23 - öv

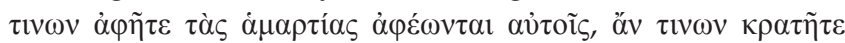

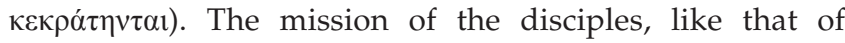
Jesus, should revolve around drawing people to God, and being representatives of God, the sender, and agents of his restorative mission of reconciliation (3:16). The same principles found in God's sending of Jesus, also applies to the disciples. The disciples are called to be subordinate to the missional plan of God (the missio Dei). Their actions should be in accordance with the will of the Father. To enable them to do just that, and to know what they should do, Jesus promised them in John 15:26-27 that once he has gone back to his Father, he will send the Paraclete or Advocate who will guide them and remind them of his words. The Spirit of Truth goes out from the Father himself, and he will testify and remind them about Jesus (15:26). Consequently, the disciples must also testify about that which they have experienced from the beginning of their journey with Jesus (15:27) and make sure that they do not fall away 16:1), especially in the context of persecution and hardship (16:2-4). Naturally this will also be true for those who follow Jesus after the disciples have died.

\section{God's plenipotentiaries: Sensitivity towards outsiders or only insiders?}

Some scholars argued that John's Gospel is a sectarian Gospel with no sensitivity towards outsiders. Hays (1996:139) correctly points out that scholars like Richard Niebuhr in, Christ and culture, chose 1 John as his example of the notion of 'Christ against culture' mentality which represented sectarian tendencies in early Christianity. Similarly, the famous Ernst Käsemann (1968:59), as also correctly interpreted by Hays (1996:139) stated that John does not demand love for enemies, but only for brothers or insiders. Against the background of the plenipotentiary idea, and given the fact that God's mission in John is purely motivated by love and compassion for humanity $(3: 16 ; 20: 30-31)$, it perhaps does not do justice to John's Gospel if it is argued that John is exclusively sectarian in his moral vision. It would thus not be fair to judge the moral vision of John's Gospel as being 'weak' or having 'moral bankruptcy' as Jack T. Sanders (1975:100) would have it. This would come down to a misinterpretation of John's missionary motive which is driven by love and sacrifice for the sake of granting life to people (or the world). Neither was the disciples called to be plenipotentiaries with an exclusive intracommunal focus. For that reason, Köstenberger (2014) is correct when he argues:

Mission and ethics are closely related in John's Gospel. The mission theme in the Fourth Gospel is pronounced and seems hard to accommodate in a sectarian reading of the Gospel. More likely, it promotes the Johannine ethic of love, unity, service, and outreach to outsiders. Against those who contend that John has no ethics to speak of, or that John's ethic is wrong or mistaken, it is argued that John's moral vision at its core consists in a belief of 
the power of love. The ethic of love is set within a framework of John's mission motive: love is extended not only to those in one's community but also to those in the world. (p. 171)

Consequently, Kok (2011:14) argues that John has a 'missional incarnational ethos' and wants his readers to imitate Christ who illustrated the transcendence of socio-cultural boundaries. John's Jesus is presented as One who was particularly interested in those on the margins of society (4:1-42; Jn 5:1ff.; 9:1). One example is Jesus' interaction with the Samaritan woman (4:1-42). Jesus initiated and facilitated a space in which the unclean Samaritan woman could receive life in fullness. Jesus reached out to the other of his day, beyond the accepted social boundaries. Jesus even asked her for something to drink, which would have made him ritually unclean. Jesus broke down the boundaries between insiders and outsiders and expressed a profound sense of sensitivity and love towards outsiders. This was part of his mission and calling which he received from his Father. When Jesus calls on his followers to be sent, just as he was sent, it implies that they too should do the works of the Father. God's mission, or the missio Dei in John is 'motivated by love for a hostile and unreceptive world' (Köstenberger 2014:172). In the same way, believers are called to be taken up and to continue this mission as God's plenipotentiary agents. God's children or Jesus-followers should be known by the love they express, which is motivated by the same love God had when he decided to send his Son to this world.

\section{Conclusion}

In summary we can deduce the following about John's idea of mission and the Jewish ideas of agency (cf. Borgen 1986:72):

- There is a strong sense of unity between the sender and the agent.

- The agent is always in service of, and subordinate to the sender, and is obliged to be obedient to the will of the sender.

- The sender empowers the agent to act on his behalf.

- The agent should be treated in the same way the sender would have been treated.

- After successful completion of the mission, the agent reports back to the sender.

- The sender might appoint other agents to continue the mission, or the agent might do so on behalf of the sender based on the first and third points.

When reading John, the (on-going) missional dimension should play a determinative role as Leitmotiv in the interpretation of John's Gospel. John's Jesus was sent by God on a mission to save this world from eternal spiritual death. After having illustrated that he is the plenipotentiary of God and the source of life by means of the resurrection, Jesus empowered and commissioned his followers as agents of God's reconciling mission.

\section{Acknowledgements}

Some of the perspectives in this article were taken from, and developed within the $\mathrm{PhD}$ thesis of the author at the University of Pretoria (Kok 2008). The author was a D.A.A.D bursary holder at the University of Bonn in Germany whilst doing this research in 2007.

\section{Competing interests}

The author declares that he has no financial or personal relationship(s) that may have inappropriately influenced him in writing this article.

\section{References}

Anderson, P.N., 2015, 'The having-sent-me-Father: Aspects of agency, encounter and irony in the Johannine Father-Son relationship', Semeia, viewed 30 Apr. 2015, from http://www.academia.edu/11558065/ The Having-Sent-Me-Father Aspects of_Agency_Encounter_and_Irony_in_the__Johannine_Father-Son_Relationship_-

Borgen, P., 1968, 'God's Agent in the Fourth Gospel', in J. Neusner (ed.), Religions in antiquity, pp. 137-148, Brill, Leiden.

Borgen, P., 1986, 'God's Agent in the Fourth Gospel', in J. Ashton (ed.), The interpretation of John, pp. 67-78, Fortress, Philadelphia. (Issues in Religion and Theology 9).

Bühner, J.A., 1977, Der Gesandte und sein Weg im 4. Evangelium: Die kultur- und religionsgeschichtlichen Grundlagen der johanneischen Sendungschristologie sowie ihre traditionsgeschichtliche Entwicklung, Mohr Siebeck, Tübingen.

Bunim, I.M., 2002, Ethics from Sinai: A wide-ranging commentary on Pirkei Avos, Feldheim, Nanuet.

Carson, D.A., 1991, The Gospel according to John, Eerdmans, Grand Rapids.

Gnilka, J., 1985, Johannesevangelium, 2. Ausgust, Echter Verlag, Würzburg.

Haenchen, E., 1980, Das Johannesevangelium, Mohr Siebeck, Tübingen.

Harvey, A.E., 1987, 'Christ as Agent', in L.D. Hurst \& N.T. Wright (eds.), The glory of Christ in the New Testament: Festschrift G.B. Caird, pp. 238-250, Oxford University Press, Clarendon. http://dx.doi.org/10.1093/acprof:oso/9780198263265.003.0018

Hays, R., 1996, Moral vision of the New Testament, Harper, San Francisco.

Hendriksen, W., 1976, Gospel of John, Banner of Truth, London.

Käsemann, E., 1968, The testament of Jesus: A study of the Gospel of John in the light of chapter 17, trans. Gerhard Krodel, Fortess, Philadelphia.

Keener, C.S., 2003, The Gospel of John, 2 vols., Hendriksen, Peabody.

Kok, J., 2008, 'Siekte en gebrokenheid teenoor genesing en restourasie in Johannes', Departement Nuwe Testament, PhD-proefskrif, Universiteit van Pretoria, Pretoria.

Kok, J., 2011, 'The dynamic relationship between mission and ethics in John', Paper presented at Queens College, Oxford.

Köstenberger, A.J., 2004, John: Baker exegetical commentary on the New Testament, Baker, Grand Rapids.

Köstenberger, A.J., 2014, 'Sensitivity to outsiders in John's Gospel and letters and its implication for the understanding of early Christian mission', in J. Kok, T. Nicklas, D.T. Roth \& C.M. Hays (eds.), Sensitivity towards outsiders, pp. 171-186, Mohr D.T. Roth \& C.M. Hays (eds.), Sensitivity towards outsiders, pp. 171-186, Mohr
Siebeck, Tübingen. (Wissenschaftliche Untersuchungen zum Neuen Testament [WUNT] 2/364).

Louw, J.P. \& Nida, E.A., 1996, Greek-English lexicon of the New Testament: Based on semantic domains, United Bible Societies, New York.

Rengstorf, H., 1964, 'Apostello' in G. Kittel, G.W. Bromiley \& G. Friedrich (eds.), Theological dictionary of the New Testament, vol. 1, Eerdmans, Grand Rapids.

Sanders, J.T., 1975, Ethics in the New Testament: Change and development, Fortress, Philadelphia.

Schnackenburg, R., 1971, Das Johannesevangelium, Herder, Freiburg. (Herders Theologischer Kommentar zum Neuen Testament 4).

Van der Watt, J.G., 2000a, Family of the king, Brill, Leiden. (Biblical Interpretation Series).

Van der Watt, J.G., 2000b, 'Die teologie van die Johannesevangelie en briewe', lesingmateriaal, Departement Nuwe Testament, Universiteit van Pretoria, Pretoria.

Waldstein, M., 1990, 'The mission of Jesus and the disciples in John', Communio International Catholic Review 17(3), 310-333.

Witherington, B., 1995, John's wisdom: A commentary on the fourth Gospel, Westminster John Knox Press, Louisville. 